\title{
特集「生物多様性と造園学」にあたって
}

\section{Biodiversity and Landscape Architecture}

\author{
担当編集委員 高橋 進 - 倉本 宣・北村圭一
}

\section{特集の趣旨}

生物多様性は 1980 年代に誕生した新しい概念であり, レッドデータブックの刊行や生物多様性条約の成立を契機 として, 生物学研究分野としてのみならず，広く環境政策 をはじめとする各種政策や社会全体の規範を構成するまで になってきている。

一方で, 生物多様性の概念は幅広く, 必ずし屯一般的に は明確になっていない。生物多様性の対象としては, 希少 野生生物から身近な生き物までの遺伝子, 種, 生態系の各 レベルがあり，その保全と利用のための具体的対応として 屯, 生物多様性国家戦略策定, 各種計画・政策への生物多 様性の組み込み, 環境影響評価, 保護地域の指定・管理, 生態系の修復・復元, 種の回復と生息地への再導入, 移入 種への対策などの各事項における研究, 教育, 政策, 国際 協力など広範囲である。

こうした広範な生物多様性の確保を現場で担っているの は, 人と自然の空間的関係学である造園学徒であることが 多い。これまで造園学会あるいはランドスケープ研究にお いては, 生態工学研究委員会でビオトープや移入種などを 取り上げたほか，国土デザインの観点から保護地域やグリー ンコリドーなど，また都市や農山村などでの自然環境の保 全と整備など，生物多様性に関連する分野を幅広く取り上 げている。

しかし, 本誌ランドスケープ研究として, 生物多様性は いまだ正面からは扱っていない。そこで，この特集では， 生物多様性に馴染みの浅い読者にあ概要が理解いただける ようにするとともに，生物多様性を造園学の中によ゙のよう に位置づけ，造園家が関わっていくことができるのか，そ して造園家がその役割を果たすことによって生物多様性の 保全の成果があがるのかを論じたい。前述のとおり，生物 多様性の具体的対応は広範であり, 生物学的に大きく分け ると種アプローチと生態系アプローチとがある。紙面の都 合上これらすべてを取り上げることはできず，またこの巻 では既にランドスケープエコロジーの特集を刊行している ので，本特集では種アプローチに焦点を合わせることとし た。

\section{特集の構成}

本特集は, 生物多様性についての総論, 種アプローチの 各論およびまとめの座談会の 3 部から構成されている。

総論では, これまでの研究や政策の動向を取りまとめ, 生物多様性概念の全体像あるいは造園学との関わりを把握 できるように努めた。まず，ランドスケープ研究その他研 究誌における生物多様性に関連する研究の紹介・レビュー をしていただいた。政策関連の 3 編では, まず地球環境政 策における生物多様性概念の変遷之国内生物多様性保全政 策の変遷を論じていただいた。次に，生態系に配慮したま ちづくりの計画論や取組事例をご紹介いただき，最後に生 物多様性国家戦略の概要と見直しにあたっての考え方など を示していただいた。

種アプローチの各論では, 研究者の方々から, それぞれ の分野での研究や保全の取り組みについて論じていただい た。絶滅種対策の基となるレッドデータブックについては, 作成への参画体験を通じて今後の問題点などを論じていた だいた。猛禽類とッキノワグマについては，それぞれ生態 的特色や我が国における生息状況をご紹介いただくととも に，保全管理について論じていただいた。既に野生では絶 滅したコウノトリについては, 絶滅の経過と野生復帰に向 けての研究をご紹介いただいた。最後に，植物種保全の観 点から，植生管理を通じての造園家と生物多様性保全の関 わりについて提言いただいた。

座談会は東京港野鳥公園において実施し，コアジサシの 繁殖誘致をケーススタディに，生物多様性の保全整備のあ り方などを討論していただき,「生物多様性と造園学」の まとめとした。

以上, 今回の特集は, 紙面の都合で広範にわたる生物多 様性分野の一部を取り上げたに過ぎず，造園学徒として生 物多様性にどう関わればよいのか，当初の意気込みほどに は答えを提供するまでには至らなかった。しかし，本特集 が少しでも, 読者の生物多様性の理解を深め, 生物多様性 と造園学を考える際の参考になれば幸いである。最後に， 急な原稿依頼にもかかわらず，ご多忙中執筆いただいた皆 様に，この場を借りて厚くお礼申し上げたい。 